\title{
Space-temporal Dynamics of Agriculture in the Primavera Municipality, Pará State, Brazil: Subsidies for Agroecological Transition
}

Caio Cezar Ferreira de Souza, Marcos Antônio Souza dos Santos, Fabrício Khoury Rebello, Cyntia Meireles Martins

Federal Rural University of Amazon (UFRA), Brazil

Maria Lúcia Bahia Lopes

University of Amazon (UNAMA), Brazil

Antônia do Socorro Aleixo Barbosa

Agroplan Sustainable Development Business Consulting, Brazil

Received: Feb. 27, 2020

Accepted: Apr. 2, 2020

Published: Apr. 13, 2020

doi:10.5296/jas.v8i2.16539

URL: https://doi.org/10.5296/jas.v8i2.16539

\begin{abstract}
The exploitation of natural resources to meet human needs for, among other reasons, the advancement of agriculture, livestock, and mining projects, causes changes in environmental systems in time and space. The research objective of this study is to evaluate the space-temporal dynamics of agriculture in the Primavera municipality, located in the Pará Northeast, from 1980 to 2018, and to offer subsidies for the agroecological transition of current agricultural production systems. The methodology is based on the analysis of land use and land cover maps, in three different periods (1984, 2008 and 2018), by using image processing from the LANDSAT (1984 and 2008) and Sentinel (2018) satellites. Agricultural sector characterization was also analyzed, by using secondary data on socioeconomic and productivity variables. The results show that, even after the setup of a large mining enterprise in the Primavera municipality, the agricultural sector did not show major changes in terms of land occupation, increasing from $23.3 \%$ (2008) to $29.3 \%$ (2018). In addition, when analyzing the agricultural sector, the technology level was found to be at a low level, with little use of chemical inputs and machines. Agricultural diversification was also found to be at a low level, with the cultivation of five crops, predominantly. It is necessary to seek alternatives to improve agricultural production, which can be made viable through the incorporation of sustainable production systems, based on agroecological principles.
\end{abstract}


Keywords: agroecology, Amazon, land use and occupation, production system, Pará Northeast

\section{Introduction}

Pará Northeast is the oldest frontier of colonization in Pará state, Brazilian Amazon, and since the $19^{\text {th }}$ century, it has been an important supplier of inputs for the Pará economy. This colonization had a direct impact on land use and occupation; currently only $35 \%$ of this territory is covered by dense vegetation (Rebello and Homma, 2017; Corderro et al., 2017).

The occupation of the region was made, predominantly, by family farmers, who, according to Rego and Kato (2017), used cutting and burning as the main practice of preparing areas for cultivation, thus causing the expansion of deforestation in small areas, leading to changes in the natural landscape.

Landscape modifications can be managed through geoprocessing techniques to mitigate problems related to the indiscriminate use of natural resources, in addition to serving as a basis for formulating public policies that foster sustainable development (Coelho et al., 2014).

In agriculture, sustainability has been a growing trend in recent decades, with the search for environmentally friendly, socially just, and economically viable food production practices (Wezel et al., 2014). Thus, the implementation of agroecological practices, primarily in family farming production systems, is an alternative for the rollout of sustainable development in rural areas.

The agricultural space of the Primavera municipality, located in Pará Northeast, is occupied mostly by small producers. Since the installation of a mining and cement production company, in 2014, the municipality underwent processes that may have modified its structure, due to the intense migratory flow from local populations and other regions, aiming to meet the demand for labor that was stimulated by the production company.

Geotechnology has become an essential tool in visualizing such changes. Menke et al. (2009) analyzed the evolution of agriculture, using remote sensing data, in the municipality of Luis Eduardo Magalhães (BA). Spagnolo et al. (2012), investigated the dynamics of agricultural expansion in the municipality of São Desidério (BA), using satellite images. Formaggio and Sanches (2017) stated that the use of geoprocessing techniques is essential in monitoring agricultural activities, as they guarantee assessments of large areas, in a short time period.

Production in the rural areas of the Primavera municipality has declined. However, there is a lack of research in the Brazilian Amazon to address this. Specifically, land use and occupation should be evaluated, using official data from Agricultural Censuses, placing agroecological practices as a possible path to rural development. With the intention of addressing the above gaps, this research aims to assess the spatial and temporal dynamics of agriculture in the Primavera municipality, from 1980 to 2018, and to offer subsidies for the agroecological transition of agricultural production systems. 


\section{Macrothink}

\section{Material and Methods}

\subsection{Study Area Characterization}

The Primavera municipality, located in Pará Northeast mesoregion and Bragantina microregion, originated from the Capanema and Salinópolis municipalities, which had their territories separated by Law 2,460 of December 29, 1961 (Primavera, 2020). It is $205 \mathrm{~km}$ away from Belém city (Pará state capital), with access via the BR-316, PA-124, and PA-446 highways. The estimated population for 2019, according to data from the Brazilian Institute of Geography and Statistics (IBGE), is 10,825, with a demographic density of 41.86 inhab. $/ \mathrm{km}^{2}$.

It has an area of $258.6 \mathrm{~km}^{2}$, located at the geographical coordinates of $0^{\circ} 56^{\prime} 31^{\prime \prime}$ south latitude and $47^{\circ} 7^{\prime} 4$ " west longitude. Its neighboring municipalities are São João de Pirabas, Quatipuru, and Tracuateua (Figure 1).

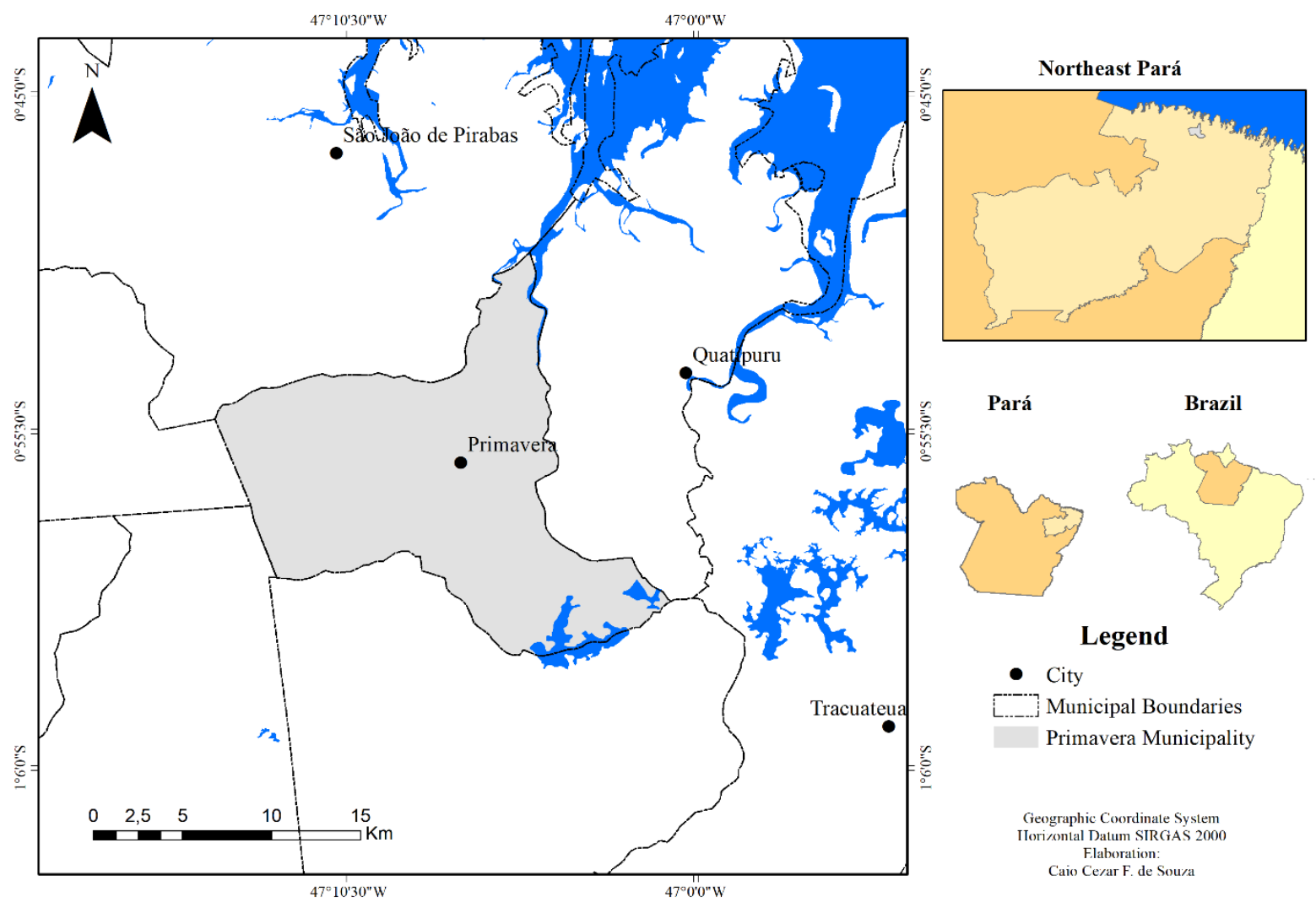

Figure 1. Location map of the Primavera municipality

Source: Prepared by the authors.

The municipality's economy underwent important changes; until 2015, it was based on the service sector, with emphasis on the public sector, and on agriculture. However, after the mining and cement manufacturing company started operating in 2016, the industrial sector started to contribute significantly to municipal Gross Domestic Product (GDP). In 2017, it was responsible for $42.23 \%$ of the GDP, while agriculture and livestock contributed with only $3.19 \%$. 


\subsection{Methodological Procedures for Identifying Land Use and Occupation}

The preparation of land use and occupation maps took place in four stages (Figure 2). The first consisted of selecting and acquiring images that cover the Primavera municipality, the second was image pre-processing, the third involved image classification, and the fourth was land use and occupation chart production, on a scale of 1: 500,000.

$1^{\text {st }}$ stage - Image selection and acquisition

- Landsat 5 (1984 and 2008)

- Scene 223/61

- Sentinel 2 (2018)

- Scene $23 \mathrm{MKU}$ and $23 \mathrm{MKV}$

$4^{\text {th }}$ stage - Land use and occupation chart
production
- Classes
- Water
- Vegetation
- Agriculture
- Urban area
- Mining

$4^{\text {th }}$ stage - Land use and occupation chart production

- Classes

- Water

Vegetation

- Urban area

- Mining $2^{\text {nd }}$ stage - Image pre-processing

- Lansat 5 (1984 and 2008)

- Composition RGB (Bands 5,4 and 1)

- Study area clipping

- Sentinel 2 (2018)

- Mosaic

- Composition RGB (Bands 11, 8 and 2) - Study area clipping

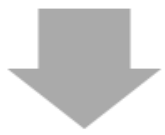

$3^{\text {rd }}$ stage - Image classification

- Signature file creation

- Iso Cluster

- Unsupervised classification

- Maximum likelihood classification

- Settings

- Visual analysis

Figure 2. Methodological procedures flowchart

Source: Prepared by the authors.

In the first stage, after identifying the scenes that covered the Primavera municipality, orbit 223 and point 61 of LANDSAT 5 and scenes 23MKU and 23MKV of Sentinel 2, the best images were selected, that is, those that had the least cloud coverage, from different periods, to demonstrate the changes in land use and occupation since the 1980s. These changes were caused mainly by the mining project implementation, which started in 2014. Given the above, images were selected from the Sentinel 2 satellite for 2018, spatial resolution of $10 \mathrm{~m}$; and from the LANDSAT 5 satellite for 2008 and 1984, spatial resolution of $30 \mathrm{~m}$. These images were obtained from the United States Geological Survey (USGS) portal. Images from the Sentinel satellite were used in the last period, because there are no images with low cloud coverage from the LANDSAT satellite.

During image pre-processing, a false color composition was performed for each period, with bands 5, 4, and 1 for the LANDSAT 5 satellite and bands 11, 8, and 2 for the Sentinel 2 satellite. These bands represent the SWIR 1, near infrared bands, and blue, respectively. 
According to Santos et al. (2014) this is the best composition for evaluating agriculture. The scenes were projected for Datum SIRGAS 2000, in the Universal Transverse Projection System of Mercator (UTM), Zona 23 Sul. Next, the mosaic was made with scenes $23 \mathrm{MKU}$ and $23 \mathrm{MKV}$ of Sentinel 2, along with the clippings necessary to obtain only study area images for each selected year.

The image classification process was carried out using ArcGIS Desktop 10.5 software, and was divided into two stages. In stage one, the Iso Cluster algorithm was used, a tool that uses clustering to create a signature file, which will be used in unsupervised classification. In stage two, the maximum likelihood method was used to obtain the different classes of land use and occupation. Some manual adjustments were also made through visual analysis, to correct some polygons that were identified in the wrong classes.

Finally, the land use and occupation map from the Primavera municipality was elaborated, and five classes were identified: water, vegetation, agriculture, urban area, and mining. In addition, areas for each identified class were calculated based on the polygons that resulted from the classification.

\subsection{Methodological Procedures for Identifying Land Use and Occupation}

The socioeconomic and productive characterization of the agricultural sector in the Primavera municipality, was carried out using data from the IBGE's Agricultural Census and the Municipal Agricultural Production (PAM) survey. To create agricultural technology level indicators in the Primavera municipality, Pará Northeast, and Pará state, information about the characterization of agricultural properties was collected, for 2006 and 2017. This data included access to electricity, agricultural practices, use of machines, access to technical assistance, associations, access to financing, and use of inputs.

The following information was sourced from the Municipal Agricultural Production (PAM) survey for the five main crops of the Primavera municipality, from 1980 to 2018: contribution to the agricultural production gross value (APGV); the amount of area harvested; quantity produced; and productivity. The objective was to identify the degree of importance of each crop over time.

\section{Results and Discussion}

Table 1 presents the results from the land use and land cover classifications, by mapped classes, for the years evaluated. In the last period, the results show an increase in urbanization and mining, in the municipality. According to the Census (IBGE, 2010), 62\% of the population of Primavera lives in urban areas, which, in 2018, represented $0.6 \%$ of the municipality's total area, thus indicating a large population concentration in urban areas.

Initially, there was a decrease of $1.2 \%$ in the area occupied by agricultural activity, from 1984 to 2008 . This increased by $6 \%$ in 2018 , which is not consistent with the data presented by the Agricultural Censuses of 2006 and 2017, which showed property areas of 9,054 hectares and 4,877 hectares, respectively. However, this divergence may be explained as follows. Agricultural use does not only include cultivation areas, and, in many instances, can be confused with secondary vegetation in the regeneration phase. 


\section{Macrothink}

Table 1. Area occupation percentage, by class, in the years 1984, 2008, and 2018.

\begin{tabular}{l|l|l|l}
\hline Classes & 1984 & 2008 & 2018 \\
\hline Water & $8.0 \%$ & $3.5 \%$ & $3.4 \%$ \\
\hline Vegetation & $67.2 \%$ & $72.7 \%$ & $66.2 \%$ \\
\hline Agriculture & $24.5 \%$ & $23.3 \%$ & $29.3 \%$ \\
\hline Urban area & $0.3 \%$ & $0.5 \%$ & $0.6 \%$ \\
\hline Mining & $0.0 \%$ & $0.0 \%$ & $0.5 \%$ \\
\hline
\end{tabular}

Source: Prepared by the authors.

Figure 3 highlights that agriculture in Primavera is mainly composed of family farming, since mainly small fragmented areas are observed, especially in the central municipality area. This pattern is confirmed by analyzing data from the last Agricultural Census. In 2006, $41 \%$ of agricultural properties occupied areas smaller than 10 hectares; this increased to $73 \%$ in 2017. Additionally, of the 388 properties registered in the last survey, 380 were considered family farmers. In the mapping carried out for 2008 and 2018, it is also possible to identify the appearance of a different pattern in the western area of the municipality, showing a concentration of large extensions of area covered by agriculture and livestock. This region is close to two state highways, PA-124 and PA-446, which justifies the installation of larger agricultural establishments, due to the easy flow of production. According to the 2017 Census of Agriculture, all establishments, with areas greater than 200 hectares, are associated with economic activity in livestock and other livestock (poultry, pigs, goats and sheep). 
1984

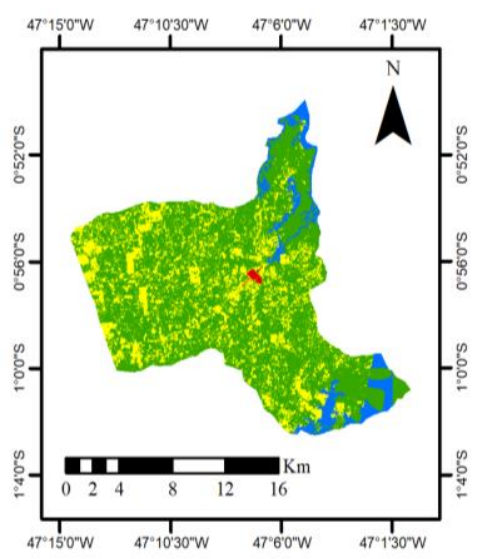

2008

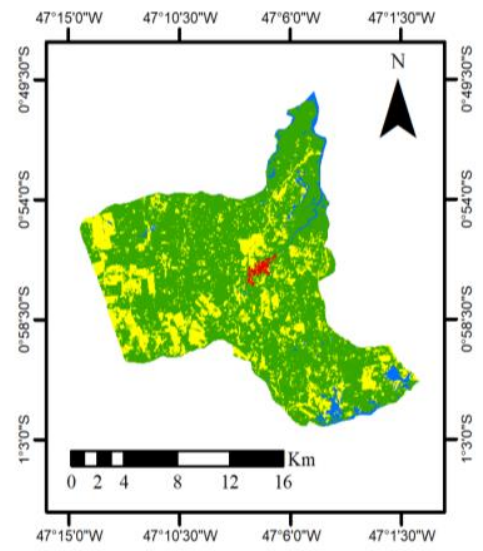

Legend
2018

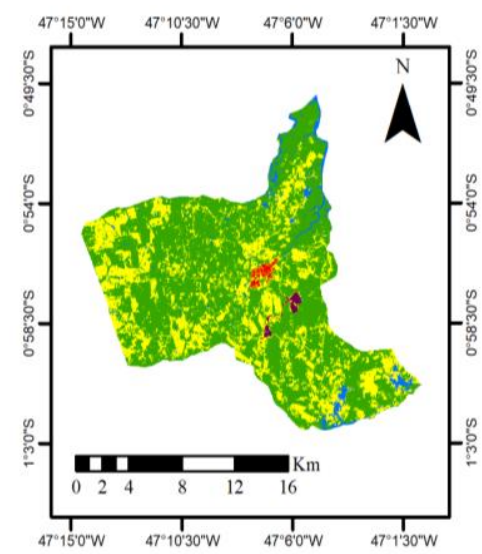

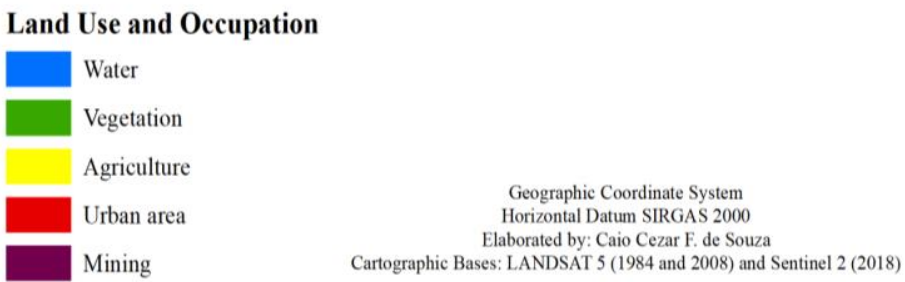

Figure 3. Land use and occupation map for the Primavera municipality in the years 1984, 2008, and 2018

Source: Prepared by the authors.

The results of the land use and occupation classification also showed that the installation of the mining and cement production company (limestone extraction), did not cause significant changes in the percentage of area occupied by each class. However, the project is still in its initial phase of operation, and may in the medium- and long-term cause significant impact. Oliveira et al. (2018) identified major changes in the landscape of Santana do Cariri (CE), which were caused by large craters that resulted from the limestone mining activity.

In the Capanema municipality, located $35 \mathrm{~km}$ from Primavera, the installation of a similar enterprise, which extracts limestone, caused significant changes in the living conditions of local residents. The local community did not receive any type of investment related to employment, sanitation, education and health; instead, it was only affected by the negative environmental impact (Kalife, 2013). To prevent this from occurring in Primavera municipality, it must be addressed within the scope of public policy, and the mining company's socio-environmental compensation instruments.

The predominance of small properties and family farming, as identified by the land use and occupation classification, showed a fundamental characteristic, which can be used to propose agroecological practices. It is important to highlight other peculiarities of agricultural production in the Primavera municipality, such as the technology level and the diversification of cultivated species, which are important to guide agroecological transition strategies. 
To assess the technology used in the rural environment, we utilized data from the Agricultural Censuses of 2006 and 2017. Table 2 shows that, in the Primavera municipality, the use of tractors and irrigation is low, with agricultural vehicle use decreasing in the analyzed period. This may be directly related to the size of rural enterprises, which makes it difficult to access finance, a very common reality in rural areas throughout Pará state.

Pesticide use, despite having increased in 2017, is still low when compared to other reference areas, such as Pará Northeast and Pará state. Fertilization use, which presents indexes close to the reference regions, can be considered an differentiated, since, in the Primavera municipality, there is a prevalence of organic fertilizer.

The use of agricultural practices, such as crop rotation and fallow or soil rest, decreased between 2006 and 2017. Rebello and Homma (2017) described the conditions in the municipalities of Pará Northeast as being similar to those of the early 1990s, where rudimentary technologies were used, for example, the use of fire to prepare the area. . Rebello et al. (2011) stated that the Primavera municipality lost dynamism in terms of its technology level in agriculture, in the period between 1996 and 2006.

Since agroecological production enables efficiency, by using fewer resources and a low level of technology, its implementation would be highly beneficial for local farmers (Altieri and Toledo, 2011). However, its integration with support institutions, such as technical assistance, rural extension services, and agents that provide financial resources, is still not well developed, which, in this case, can hinder the dissemination of agroecological practices among agricultural establishments.

Table 2. Agricultural technology level indicators in the Primavera municipality, Pará Northeast, and Pará state, for 2006 and 2017

\begin{tabular}{c|c|c|c|c|c|c}
\hline \multirow{2}{*}{\begin{tabular}{c} 
Indicators (\%) \\
\cline { 2 - 7 }
\end{tabular}} & \multicolumn{2}{|c|}{ Study area } & \multicolumn{4}{c}{ Reference area } \\
\cline { 2 - 7 } & 2006 & 2017 & 2006 & 2017 & 2006 & 2017 \\
\cline { 2 - 7 } $\begin{array}{c}\text { Number of establishments receiving } \\
\text { technical guidance }\end{array}$ & 10 & 8 & 7 & 5 & 10 & 6 \\
\hline $\begin{array}{c}\text { Number of establishments with planting use } \\
\text { indication at level }\end{array}$ & 4 & 0 & 21 & 2 & 15 & 2 \\
\hline $\begin{array}{c}\text { Number of establishments with crop rotation } \\
\text { use indication }\end{array}$ & 6 & 1 & 3 & 11 & 3 & 8 \\
\hline $\begin{array}{c}\text { Number of establishments with fallow or } \\
\text { soil rest use indication }\end{array}$ & 1 & 1 & 5 & 16 & 4 & 10 \\
\hline $\begin{array}{c}\text { Number of establishments with use } \\
\text { indication of protection and/or conservation } \\
\text { of slopes }\end{array}$ & 2 & 0 & 1 & 2 & 2 & 2 \\
\hline \begin{tabular}{c} 
Number of establishments with participation \\
\hline
\end{tabular} & 16 & 18 & 35 & 18 & 40 & 17 \\
\hline
\end{tabular}




\begin{tabular}{c|c|c|c|c|c|c}
\hline \hline indication in associations and cooperatives & & & & & & \\
\hline $\begin{array}{c}\text { Number of establishments with fertilization } \\
\text { use indication }\end{array}$ & 15 & 21 & 20 & 30 & 10 & 19 \\
\hline $\begin{array}{c}\text { Number of establishments with pesticide use } \\
\text { indication }\end{array}$ & 4 & 6 & 8 & 12 & 7 & 16 \\
\hline $\begin{array}{c}\text { Number of establishments with irrigation } \\
\text { use indication }\end{array}$ & 3 & 4 & 3 & 8 & 2 & 5 \\
\hline $\begin{array}{c}\text { Number of establishments with tractor } \\
\text { ownership indication }\end{array}$ & 2 & 1 & 2 & 3 & 3 & 5 \\
\hline $\begin{array}{c}\text { Number of establishments with access to } \\
\text { financing indication }\end{array}$ & 4 & 3 & 7 & 5 & 8 & 6
\end{tabular}

Source: Prepared by the authors, using IBGE data $(2006,2017)$.

The main agricultural products in the Primavera municipality, between 1980 and 2018, were: cassava (Manihot esculenta), black pepper (Piper nigrum), corn (Zea mays), cowpea (Vigna unguiculata), and the bay coconut (Cocos nucifera). In 2018, these products accounted for 99.89\% of the agricultural production gross value (APGV). From 2004, Cassava (Manihot esculenta) became the main contributor to the composition of Spring APGV, varying from $37.5 \%$ (2006) to $84.18 \%$ (2013).

Crops such as passion fruit (Passiflora edulis), mallow (Malva sylvestris), rice (Oryza sativa), cotton (Gossypium hirsutun), and bananas (Musa spp.), which, in certain periods, were of great importance for the agricultural sector of the municipality, have been losing space over time. Figure 4 shows the dominance of the five main products (previously highlighted), since 2002. 


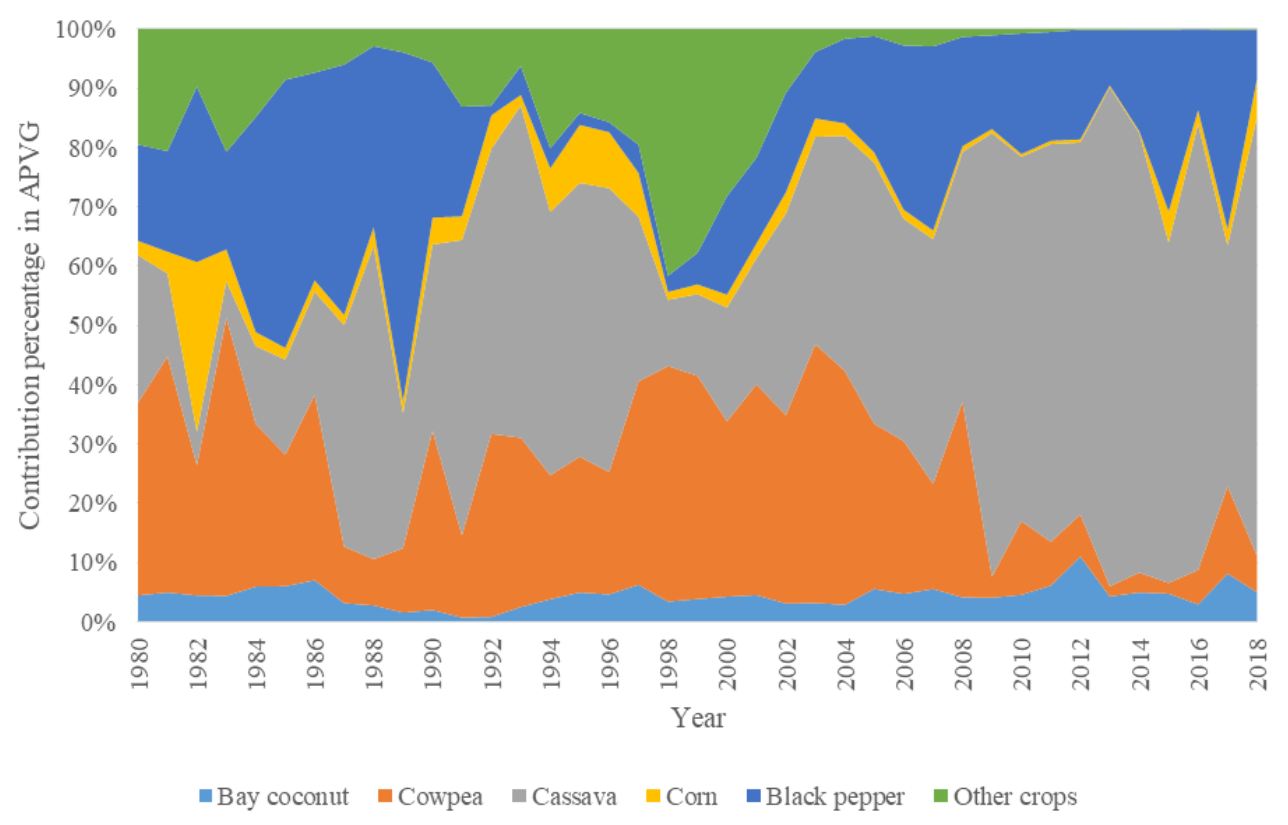

Figure 4. Evolution of the agricultural production gross value in the Primavera municipality, from 1980 to 2018

Source: Prepared by the authors, using IBGE data (2020).

The smaller time frame used in this study allows us to analyze the influence of the mining company on agricultural production in Primavera. We observed a decrease in the harvested area, and lower produced quantities of cowpea (Vigna unguiculata), corn (Zea mays), and black pepper (Piper nigrum), before the setup of the mining company (2014), which may be related to agricultural land abandonment, especially by younger farmers, in view of the expected improvement in other sectors of the economy resulting from enterprise construction.

In the period after 2014, these crops showed a small recovery, which may be related to the increase in poverty among the population, and the subsequent need for the return to family subsistence farming; however, when analyzing the entire time frame, from 2001 to 2018, this recovery was not significant, since, in general, crops showed a loss of dynamism or stagnation.

Cowpea (Vigna unguiculata) exhibits the greatest loss of dynamism, in recent years, in the Primavera municipality (as shown in Table 3). Santos and Rebello (2012), find that this crop showed drops in both harvested area and quantity produced, since the late 1990s. Further, the study indicates that the lack of effective public policies that promote agricultural modernization in the municipality is one of the main reasons for this unsatisfactory performance. 
Table 3. Geometric growth rates (\% per year) of harvested area (HA), produced quantity (PQ), and productivity $(\mathrm{P})$ of the five main crops in the Primavera municipality, from 2001 to 2018

\begin{tabular}{c|c|c|c|c|c|c|c|c|c}
\hline \multirow{2}{*}{ Crops } & \multicolumn{3}{|c|}{$2001-2014$} & \multicolumn{3}{c|}{$2014-2018$} & \multicolumn{3}{c}{$2001-2018$} \\
\cline { 2 - 10 } & $\begin{array}{c}\text { HA } \\
\text { (ha) }\end{array}$ & PQ (t) & P (t/ha) & $\begin{array}{c}\text { HA } \\
(\mathrm{ha})\end{array}$ & PQ (t) & $\begin{array}{c}\text { P } \\
(\mathrm{t} / \mathrm{ha})\end{array}$ & $\begin{array}{c}\text { HA } \\
(\mathrm{ha})\end{array}$ & PQ (t) & $\begin{array}{c}\mathrm{P} \\
(\mathrm{t} / \mathrm{ha})\end{array}$ \\
\hline $\begin{array}{c}\text { Bay } \\
\text { coconut }\end{array}$ & 9.49 & 8.91 & -0.53 & 0 & -1.89 & -1.89 & 6.22 & 3.9 & -2.18 \\
\hline Cowpea & -12.73 & -16.22 & -4.00 & 10.44 & 15.43 & 4.51 & -10.91 & -12.36 & -1.62 \\
\hline Cassava & 1.16 & 2.99 & 1.81 & -6.7 & -11.56 & -5.22 & -0.05 & 0.75 & 0.80 \\
\hline Corn & -13.53 & -14.81 & -1.49 & 38.96 & 47.79 & 6.36 & 0.18 & 1.23 & 1.04 \\
\hline $\begin{array}{c}\text { Black } \\
\text { pepper }\end{array}$ & -4.95 & -1.85 & 3.26 & 2.26 & 0.96 & -1.27 & -4.17 & -2.96 & 1.26 \\
\hline
\end{tabular}

Source: Prepared by the authors, using IBGE data (2020).

Production systems, based on agroecological principles, which seek to diversify production can be a valid alternative to increase agricultural dynamism in the Primavera municipality. These systems guarantee food sovereignty for farmers and increase resilience to natural and commercial changes. As reported by Mota et al. (2019), they have been successfully implemented in the Tomé-Açu municipality, state of Pará.

\section{Conclusion}

The classification results of land use and occupation showed that the agricultural sector is very important for the Primavera municipality, occupying about a quarter of the municipality area, in all the periods analyzed. The results also showed that the municipality is composed of small areas of production, which are occupied by family farmers.

An analysis of agricultural products revealed that the municipality has a low product diversification In addition, its farmers have limited access to technologies and support from development institutions. In view of the characteristics presented, encouraging the adoption of agroecological practices provides an alternative for agriculture development in Primavera. This will enable the provision of alternative markets and food sovereignty to small farmers in the municipality.

\section{Acknowledgement}

This study was financed, in part, by the Coordenação de Aperfeiçoamento de Pessoal de Nível Superior - Brasil (CAPES) - Finance Code 001. 


\section{References}

Altieri, M., \& Toledo, V. M. (2011). The agroecological revolution in Latin America: rescuing nature, ensuring food sovereignty and empowering peasants. The Journal of Peasant Studies, 38(3), 587-612. https://doi.org/10.1080/03066150.2011.582947

Coelho, V. H. R., Montenegro, S. M. G. L., Almeida, C. N., Lima, E. R. V., Neto, A. R., \& Moura, G. S. S. (2014). Dinâmica do uso e ocupação do solo em uma bacia hidrográfica do semiárido brasileiro. Revista Brasileira de Engenharia Agrícola e Ambiental, 18(1), 64-72. https://doi.org/10.1590/S1415-43662014000100009

Cordeiro, I. M. C. C., Arbage, M. J. C., \& Schwartz, G. (2017). Nordeste do Pará: Configuração Atual e Aspectos Identitários. In: Cordeiro I M C C, Rangel-Vasconcelos L G T, Schwartz G and Oliveira F de A. (Org.). Nordeste Paraense: panorama geral e uso sustentável das florestas secundárias. Belém, PA: EDUFRA.

Formaggio, A. R., \& Sanches, I. D. (2017). Sensoriamento Remoto em Agricultura. São Paulo: Oficina de Textos.

IBGE Instituto Brasileiro de Geografia e Estatística. Censo Agropecuário 2006. [Online] Available: https://sidra.ibge.gov.br/pesquisa/censo-agropecuario/censo-agropecuario-2006 (January 5, 2020).

IBGE Instituto Brasileiro de Geografia e Estatística. Censo Agropecuário 2017. [Online] Available: https://sidra.ibge.gov.br/pesquisa/censo-agropecuario/censo-agropecuario-2017 (January 5, 2020).

IBGE Instituto Brasileiro de Geografia e Estatística. Censo Demográfico 2010. [Online] Available: https://sidra.ibge.gov.br/pesquisa/censo-demografico/demografico-2010/inicial

IBGE Instituto Brasileiro de Geografia e Estatística. Cidades. [online] Available: https://cidades.ibge.gov.br/ (September 10, 2019).

IBGE Instituto Brasileiro de Geografia e Estatística. Produção Agrícola Municipal. [online]. Website https://sidra.ibge.gov.br/pesquisa/pam/tabelas (January 5, 2020).

Kalife, K. R. (2013). Mineração de calcário no município de Capanema, estado do Pará: uma análise a partir da percepção dos moradores do entorno da Jazida B-17. 2013. Thesis (Master in Planejamento do Desenvolvimento) - Núcleo de Altos Estudos Amazônicos, Universidade Federal do Pará, Belém.

Menke, A. B., Carvalho Junior, O. A., Gomes, R. A. T., Martins, E. S., \& Oliveira, S. N. (2009). Análise das mudanças do uso agrícola da terra a partir de dados de sensoriamento remoto multitemporal no município de Luis Eduardo Magalhães (BA - Brasil). Sociedade \& Natureza, Uberlândia, 21(3), 315-326. https://doi.org/10.1590/S1982-45132009000300007

Mota, D. M., Ribeiro, L., \& Schmitz, H. (2019). A organização do trabalho familiar sob a influência da produção de dendê em Tomé-Açu, Pará. Boletim do Museu Paraense Emílio Goeldi. Ciências Humanas, Belém, 14(2), 531-551. 
https://doi.org/10.1590/1981.81222019000200014

Oliveira, E. A. F., Figueiredo, S. S. M., Gonçalves, J. F., Batista, T. A., Home, I. C. A., \& Januário, T. L. S. (2018). Impactos ambientais oriundos da extração de calcário laminado em Santana do Cariri (CE). Natural Resources, 8(2), 21-30. https://doi.org/10.6008/CBPC2237-9290.2018.002.0003

Primavera. Prefeitura. Sobre a cidade. [Online] Available: https://www.primavera.pa.gov.br/sobre-a-cidade/ (January 5, 2020).

Rebello, F. K., \& Homma, A. K. (2017). História da colonização do nordeste paraense: uma reflexão para o futuro da Amazônia. Belém: EDUFRA.

Rebello, F. K., Santos, M. A. S., \& Homma, A. K. O. (2011). Modernização da agricultura nos municípios do Nordeste Paraense: determinantes e hierarquização no ano de 2006. Revista de Economia e Agronegócio, Viçosa, 9(2), 209-232. https://doi.org/10.25070/rea.v9i2.184

Rego, A. C., \& Kato, O. R. (2017). Agricultura de corte e queima e alternativas agroecológicas na Amazônia. Novos Cadernos NAEA, Belém, 20(3), 203-224. https://doi.org/10.5801/ncn.v20i3.3482

Santos, A. R., Eugenio, F. C., Soares, V. P., Moreira, M. A., Ribeiro, C. A. A. S., \& Barros, K. O. (2014). Sensoriamento Remoto no ArcGIS 10.2 .2 passo a passo: processamento de imagens orbitais. Alegre: CAUFES.

Santos, M. A. S., \& Rebello, F. K. (2012). Perfil socioeconômico e tecnológico dos pequenos produtores de feijão-caupi do município de Primavera, Nordeste do Pará - Brasil. Revista Verde de Agroecologia e Desenvolvimento Sustentável, Mossoró, 7(5), 72-82.

Spagnolo, T. F. O., Gomes, R. A. T., Carvalho Junior, O. A., Guimarães, R. F., Martins, E. S., \& Couto Junior, A. F. (2012). Dinâmica da expansão agrícola do município de São Desidério-BA entre os anos de 1984 a 2008, importante produtor nacional de soja, algodão e milho. Geo UERJ, 2(23), 603-618. https://doi.org/10.12957/geouerj.2012.4821

Wezel, A., Casagrande, M., Celette, F., Vian, J., Ferrer, A., \& Peigné, J. (2014). Agroecological practices for sustainable agriculture. A review. Agronomy for Sustainable Development, 34, 01-20. https://doi.org/10.1007/s13593-013-0180-7

\section{Copyright Disclaimer}

Copyright for this article is retained by the author(s), with first publication rights granted to the journal.

This is an open-access article distributed under the terms and conditions of the Creative Commons Attribution license (http://creativecommons.org/licenses/by/4.0/). 